\title{
開水路乱流における 水面変動の移流特性 \\ ADVECTION CHARACTERISTICS OF WATER SURFACE FLUCTUATIONS IN OPEN-CHANNEL TURBULENT FLOWS
}

\author{
宮本仁志 \\ Hitoshi MIYAMOTO \\ 正会員 博士 (工学) 神戶大学助教授 工学部建設学科（广657-8501 神戶市灘区六甲台町1 1)
}

\begin{abstract}
In this paper, I experimentally examine advection characteristics of water surface fluctuations in open-channel turbulent flows. Instantaneous velocity vectors and corresponding water surface profiles are measured by using an image processing technique. At first, the time series of the water-surface profiles from the measurements precisely indicate that the water-surface fluctuation is propagated with a constant advection velocity. Then, the spatiotemporal correlation analysis of the water-surface fluctuations as well as turbulence in the flows discloses that the advection velocity of the water surface fluctuation is smaller than the mean bulk velocity, while that of the turbulence of the flow is the same as the corresponding velocity of the mean velocity distribution. Also, it is found that the ratio of the advection velocity of the water surface fluctuation with the mean bulk velocity becomes smaller as the Froude number decreases.
\end{abstract}

Key Words: open-channel flow, water surface fluctuation, advection velocity, turbulence, spatiotemporal correlation analysis, simultaneous image measurement

\section{1.はしがき}

開水路流れにおける自由水表面の挙動は, 水面直下の 乱流構造に影響を及ぼすため水表面を介しての気体輸送 や運動量交換に関連し, 光の挙動解明は河川の自浄作用 など水環境の観点からも重要と考えられる．また，近年 , 実河川水面上の波紋を画像解析することにより表面流速 を推定し, 乥れより河川流量など河川計画・管理上重要 な水理量を算出しようとする画像計測手法力精力的に開 発されており1,2，自由水表面の変動(凹凸)情報が有効 に利用されはじめている．しかしながら，流速が大きく なり水面変動力湿著になる場合の水面変動と内部の乱流 構造の関連性については未解明の部分が大きく，また， 実河川画像計測の場合 , 画像の相関より推定された水面 流速か実際の河道内流速をどの程度反映するのかについ ての詳細は分からない部分が大きい．したがって，開水 路での水面変動の挙動特性を基礎的立場から的確に把握 し , 界面での流れの現象を解明することが重要と考えら れる.

本論文では，開水路での瞬時の水面分布と流速べク卜 ルを，ハイスピードカメラを用いた水面・流速の同時画

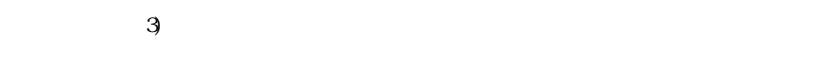
分に時空間相関解析を施すことによって，弚れら変動成 分の流下方向移流速度を評価する . また, 得られた移流 速度と内部の平均流分布などを比較することによって， フルード数の変化に伴う水面変動の移流特性を考究する . 自由表面境界を有する乱流に関する近年での実験的ア プローチとしては, 筆者らの研究 ${ }^{4}$, 需津・中山による 研究 ${ }^{7,8)}$ などか挙げられる.筆者らは, 高解像度カメラ とYAGレーザーを用いて同時画像計測 ${ }^{3}$ によって水面・ 流速を計測し，POD(proper orthogonal decomposition)と同 時空間相関解析を用いることにより，同一空間スケール をもつ水面変動成分と流体内部の乱流構造には明確な相 関があること ${ }^{4,5)}$, 水面直下における水面変動の影響層の 存在と炎のフルード数依存性包などを実験的に明らかに している．また, 襧津・中山は , レーザ一流速計と超音 波波高計を用いて乱流と水面変動を詳細に計測し，乱れ 強度，エネルギー収支の検討により水面近傍の領域では 管路流に比べて著しく乱流構造が異なるこど，時空間 相関解析により壁面近傍の組織渦と自由水面近傍の組織 渦との関連性があること齐とどを報告している．しかし ながら，著者らの研究ではYAGレーザーを用いている ために計測值の時間分解能か不足することにより，また， 
表- 1 水理条件

\begin{tabular}{|c|c|c|c|c|c|c|c|}
\hline Case & $Q\left(\mathrm{~cm}^{3} / \mathrm{s}\right)$ & $H(\mathrm{cn}$ & $\bar{U}(\mathrm{~cm} / \mathrm{s}$ & $I_{*}(\mathbf{c m} / \mathbf{s})$ & $1 / I$ & $F r$ & $R e$ \\
\hline 1 & \multirow{5}{*}{$5.0 \times 10^{3}$} & 2.0 & 102.1 & 5.17 & $1 / 65$ & 2.33 & \multirow{5}{*}{$\begin{array}{c}2.0 \\
\times \\
10^{4}\end{array}$} \\
\hline 2 & & 2.5 & 79.3 & 4.20 & $1 / 134$ & 1.60 & \\
\hline 3 & & 3.0 & 67.1 & 3.51 & $1 / 215$ & 1.24 & \\
\hline 4 & & 3.5 & 56.5 & 3.01 & $1 / 347$ & 0.96 & \\
\hline 5 & & 4.0 & 50.4 & 2.75 & $1 / 476$ & 0.81 & \\
\hline
\end{tabular}

ここに, $Q:$ 流量, $H:$ 平均水深, $\bar{U}$ : 断面平均流速, $U_{*}$ : 底面 摩察速度, $I:$ 水路床勾配, $F r=\bar{U} /(g H)^{12}$ : フルート数, $R e=$

$\bar{U} H N$ : レイノルス数, $g$ : 重力加速度,,$v$ : 動粘性係数.

後者の研究ではレーザー流速計を用いた点計測か注体の ため空間分解能力㳅足することにより, 水面変動・流速 変動の移流・伝播特性に関しては未十詳細には検討され ていないと考えられる .

\section{2. 室内水理実験と 同時画像計測}

\section{（1）水理条件}

実験水路は, 長さ $10 \mathrm{~m}$, 幅 $B=0.25 \mathrm{~m}$ のアクリ製直 線水路である . 開水路せん断乱流を起因とする水面変動 を発生させて計測するために，水路下部構造の岡性を上 げて水路の撓み極力抑え，水路側面・底面におけるアク リル水路継目のシリコン処理方法の検討を行い，また， 上流側流入口のベルマウスの設計・設置を丁寧に行った . 結果として , 実験中の水面には側壁からの波の発生は殆 ど見られなかった .さらに, 計測断面は, 水路床からの 乱流境界層か十分に発達したと考えられる，水路上流端 から約7.5mにおける水路中央鉛直断面とした . したがつ て, 今後の詳細かつ丁寧な計測值の解析は必要ではある が, 現時点では本研究て取り扱っている水面変動は開水 路せん断乱流力主要因のものと考えてよいと思われる .

水理条件を表-1に示す．実験では，レイノルズ数 $R e=\bar{U} H / v$ を $2.0 \times 10^{4}$ で一定にし, フルード数 $F r=$ $\bar{U} /(g H)^{1 / 2}$ を0.81〜2.33まで系統的に射流〜限界流〜常 流と変化させている.このフルード数Frの条件設定に際

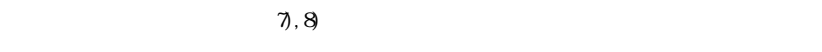
は水面変動力強調され解析力比較的容易になると考えら れる射流を中心に設定を行った . 実河川での通常の洪水 流に対応する常流条件中心の実験は今後実施する予定で ある.また , 水理条件の設定にあたつても，側壁の影響 が少なくなるように, 横断方向のアスペクト比を大きく とるようにした $(B / H>6.0)$.

（2）水面と流速の同時画像計測手法

図-1に計測システムの概要を示す . 流水中に比重か約 1.02 , 粒径0.075〜0.150mmの高分子ポリマー粒子を投入

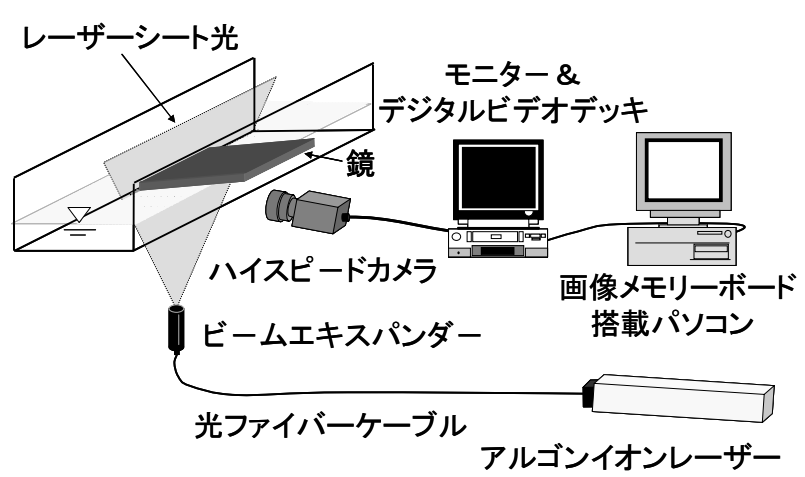

図-1 画像計測システムの概要

し，計測対象断面をレーザースリット光で可視化する． 鏡を用いることにより可視化断面での流体内部と水面形 状を同一画像フレーム内て撮影し，PIVと水面形状の抽 出アルゴリズムにより流速ベクトルと水面分布を弚れ光 れ測定する゙ ${ }^{3}$. PIV解析により得られる流速べクトルの サンプリング周波数はCase1で $400 \mathrm{~Hz}$, 弚の他のCaseで 240Hzであり，ハイスピードカメラにおける一画素の実 長は0.18〜0.36mmである . 統計解析に際しては , 後述の 図-2に示すような瞬時の流速べクトル・水深の測定デー タを約6500〜10900(実験Caseによって異なる)用いて，統 計量などを算出した .

座標系などの設定については，2次元のカーテシアン 座標系を採用し，水路床の一点を原点として流下方向に 軸を，光れに垂直な上向き方向を軸とした $. x, y$ 軸方 向の瞬間流速ベクトルの各方向成分を $u, v と し$, 時間(も しくは統計)平均流速べクトル, 変動成分の各成分を $(U$, V) , $\left(u^{\prime}, v^{\prime}\right)$, 断面平均流速を $\bar{U}(=Q / B H)$ とした . 水面 分布に関しては, 瞬時の水深をh, 平均水深および変動 成分を光れ光れ $H, h^{\prime}$ とした。

\section{3. 時空間相関解析法}

本研究では, 時空間相関係数を用いることによって， 水面の変動と内部の乱流成分の移流特性を調べる．解析 対象とした物理量は, 後述のように, 水面変動成分 $h^{\prime}$ および㐬速変動成分 $u^{\prime}$ である .

変動成分 $f\left(x_{\mathrm{ref}}, t_{\mathrm{p}}\right)$ と $g\left(x, t_{\mathrm{p}}+\mathrm{T}\right)$ との時空間相関係数 $\mathrm{COR}_{f g}(x ; \mathrm{T})$ は次式で与えられる .

$$
\operatorname{COR}_{f g}(x ; \tau)=\frac{\sum_{\mathrm{p}=1}^{\mathrm{M}} f\left(x_{r e f}, t_{\mathrm{p}}\right) g\left(x, t_{\mathrm{p}}+\tau\right)}{\left(\sum_{\mathrm{p}=1}^{\mathrm{M}} f\left(x_{\text {ref }}, t_{\mathrm{p}}\right)^{2}\right)^{1 / 2} \cdot\left(\sum_{\mathrm{p}=1}^{\mathrm{M}} g\left(x, t_{\mathrm{p}}+\tau\right)^{2}\right)^{1 / 2}}
$$




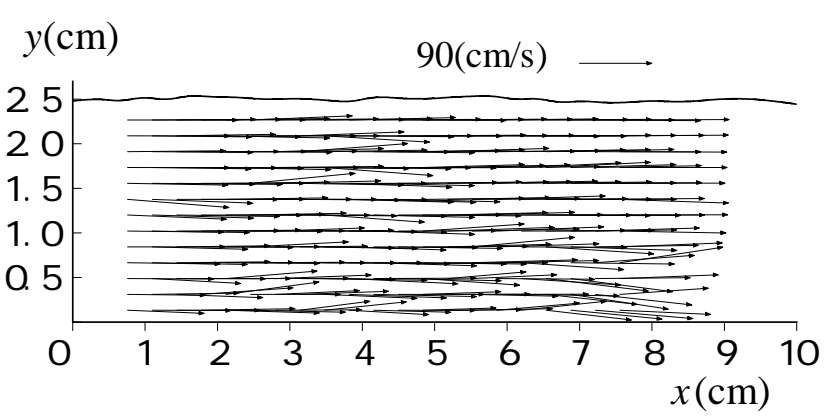

図-2 瞬時の流速ベクトルと水深分布

( Case 2: $F r=1.60$ )

$h(\mathrm{~cm})$

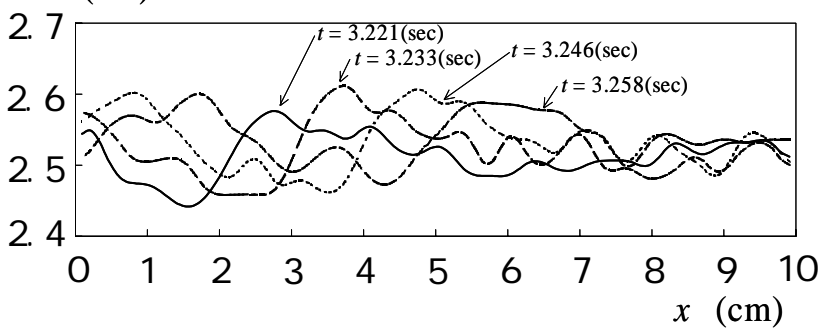

図-3 水深の経時変化 (Case $2: F r=1.60)$

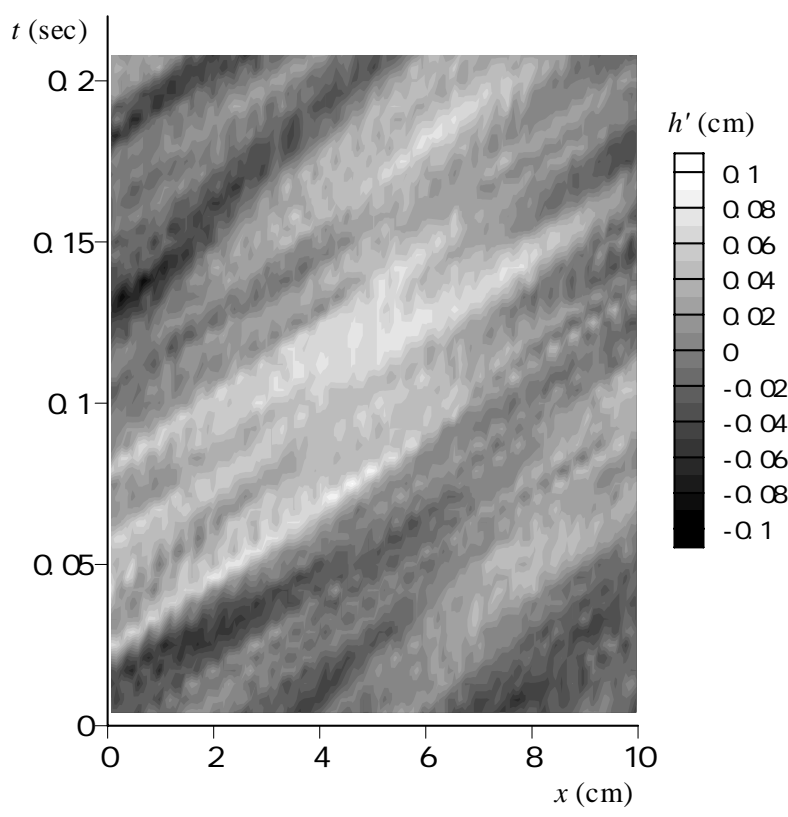

図-4 水面変動成分の時空間分布

( Case 2: $F r=1.60$ )

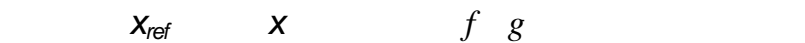
あり，下付添字” ref "は参照とする変動成分の位置べク トルであることを表す . $t_{\mathrm{p}}$ は計測の離散時間，Mは全離 散時間点数であり， T は対象とする変動成分間のラグタ イムである .

\section{4. 結果と考察}

\section{（1）瞬時の流れ場}

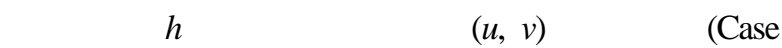
$2: F r=1.60)$ を図-2に示す . 水路床近傍の流速は，壁面 せん断によって，ある程度の空間スケールをもって上下 に変動している . 水面はほぼ水平であるが, 空間スケー ルか約3〜4cmの微小な凹凸か存在している . 画像の撮 影時間間融(1/400もしくは1/240 sec)ごとに時々刻々得ら れる，これら瞬時の流れ場のデータを用いて，以下の考 察を行う.

\section{（2）水面の経時変化}

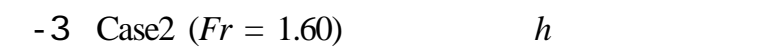
り，1/80 sec毎の水面形状が重ねて表示されている.瞬 時の水深は, 平均水深 $H$ に対して約 $\pm 0.1 \mathrm{~cm}$ の幅をもち， 流下方向に変動している.時間の経過とともに, 水面分 布は若干変形されながら下流側に移動しているのがわか

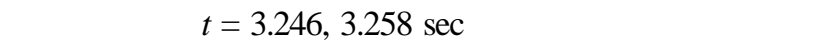
新たに現れており，水面が波動的に変動していることが 推察される.

図-4に水面の变動成分 $h^{\prime}$ の時空間分布を示す(Case $2: F r=1.60)$. 時空間 $(x-t)$ 平面上において水面変動 $h^{\prime}$ の濃淡の模樣が一定の角度をもって右上がりになってい ることから, 水面変動 $h^{\prime}$ は流下方向にほぼ一定の速度 で移流・伝播していることか確認される．また，他の Caseにおいても，この右上がりの濃淡縞模樣の分布は明 確に現れており, 各Caseにおいて水面変動 $h^{\prime}$ はほぼ一 定の移流速度をもっていることがわかった .

本研究においては,この水面変動 $h^{\prime}$ の移流速度と開水 路流れの平均流速・乱れの移流速度との関係, また, $h^{\prime}$ の移流速度に対するフルード数の依存性を調べるた めに，時空間相関解析を用いた検討を行う．弚の時空間 相関解析の前に，比較の対象となる流速成分の統計量を 次項で算出しておく.

\section{(3) 流速の統計量}

図-5に流速成分の統計量を示す . 図-5(a) は無次元平 均流速 $U^{+}$の鉛直分布であり, 図-5(b) は $x$ 方向乱れ強度 $\sqrt{\overline{u^{\prime 2}}} / U_{*}$ の鉛直分布である .ここで, 図-5(a)において， $U^{+}=U / U_{*}, y^{+}=y U_{*} / v$ である. $U^{+}$は, 図-5(a) に併示し た対数則分布とよく一致しており，限界流に近いCase 4 $(F r=0.96)$ では , 水表面近傍においてwake領域力明確に 存在していることがわかる.一方, $\sqrt{\bar{u}^{\prime 2}} / U_{*}$ の分布は， 水面に向かって減衰しており，併示した禰津らの半理論 曲線9に比較的一致している。これらより，同時画像計 測によって得られた流速べクトルにおいて，本研究て解 析対象とする $x$ 方向流速成分は, 弚の統計量力溉往の知 見と定量的にほぼ一致しており，乥れらの精度力検証さ 


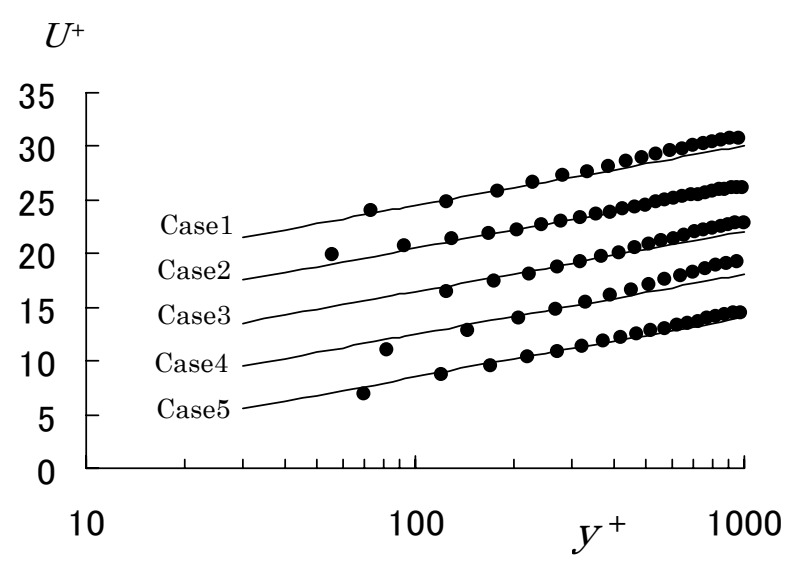

(a) $x$ 方向無次元平均流速分布 (実線は対数則分布で あり，比較のために縦軸を調整している . )

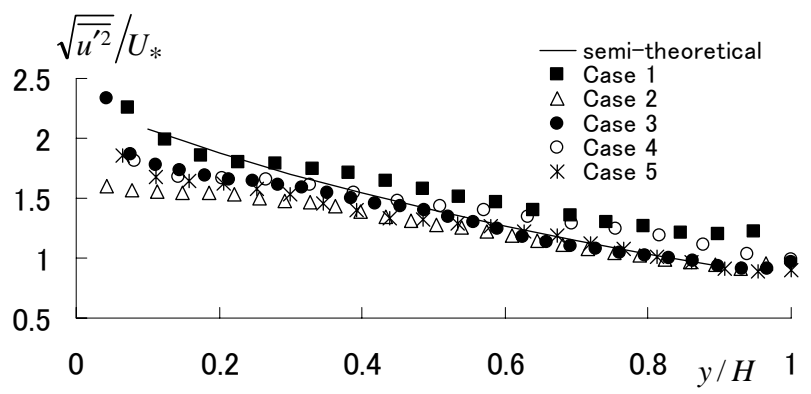

(b) $x$ 方向乱れ強度の鉛直分布

図-5 流速成分の統計量

れたと考えられる

\section{（4）水面変動· 乱れの時空間相関}

次に, 水面変動成分 $h^{\prime}$ および流速変動成分 $u^{\prime}$ が流下 方向にどのように移流・伝播しているのかを検討するた めに, 時空間相関解析(式(1))を行う.

図-6は, Case $1(F r=2.33)$ における水面変動成分 $h^{\prime}$ の 自己時空間相関係数COR ${ }_{h h}(x ; \mathbf{T})$ の流下方向分布である . 図中にはラグタイムT $=0$ から $0.075 \mathrm{sec}$ まて0.0025 sec 毎 のCOR ${ }_{h h}(x ; \mathrm{T})$ )分布が重ねて示されており，左から右 側の分布曲線になるに従ってラグタイム が大きくなる． ラグタイム $=0$ の同時相関においては , 参照位置 $x_{\mathrm{ref}}=$ $3.0 \mathrm{~cm}$ においてCOR ${ }_{h h}(x ; \mathrm{T}=0)=1.0$ 極大值をもつべル型 の分布になっており，ラグタイムT が大きくなるほど， $C O R_{h h}(x ; \mathrm{T})$ は減衰し, 極大值の現れる位置も流下方向 に移動していく.このCOR ${ }_{h h}(x ; T)$ 極大値の移動速度 が水面変動 $h^{\prime}$ の流下方向への平均的な移流速度を表す ことになる。

図-7に, Case 1(Fr = 2.33)における $x$ 方向流速变動成分 $u^{\prime}$ の自己時空間相関係数 $C O R$ u䏄間分布を示す . 参 照位置は $\{x, y\}_{\mathrm{lef}}=\{1.56,1.47\}_{\mathrm{cm}}$ であり，水面から約 $1 / 4 H$ における乱れの相関COR

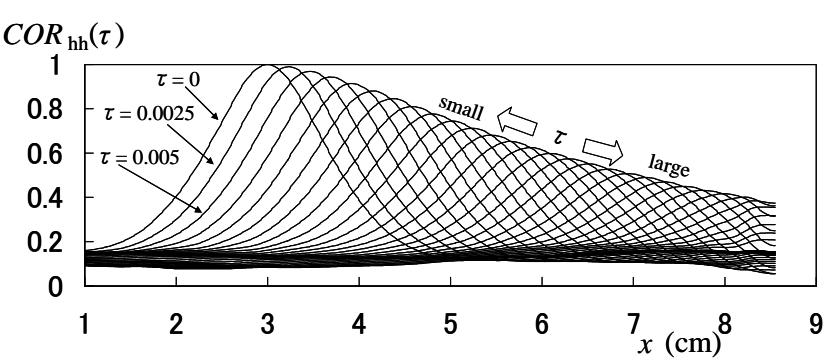

図-6 水面変動の時空間相関係数の流下方向分布

(Case 1: $F r=2.33, x_{\mathrm{Ief}}=3.0 \mathrm{~cm}$ を参照泣置としている.)
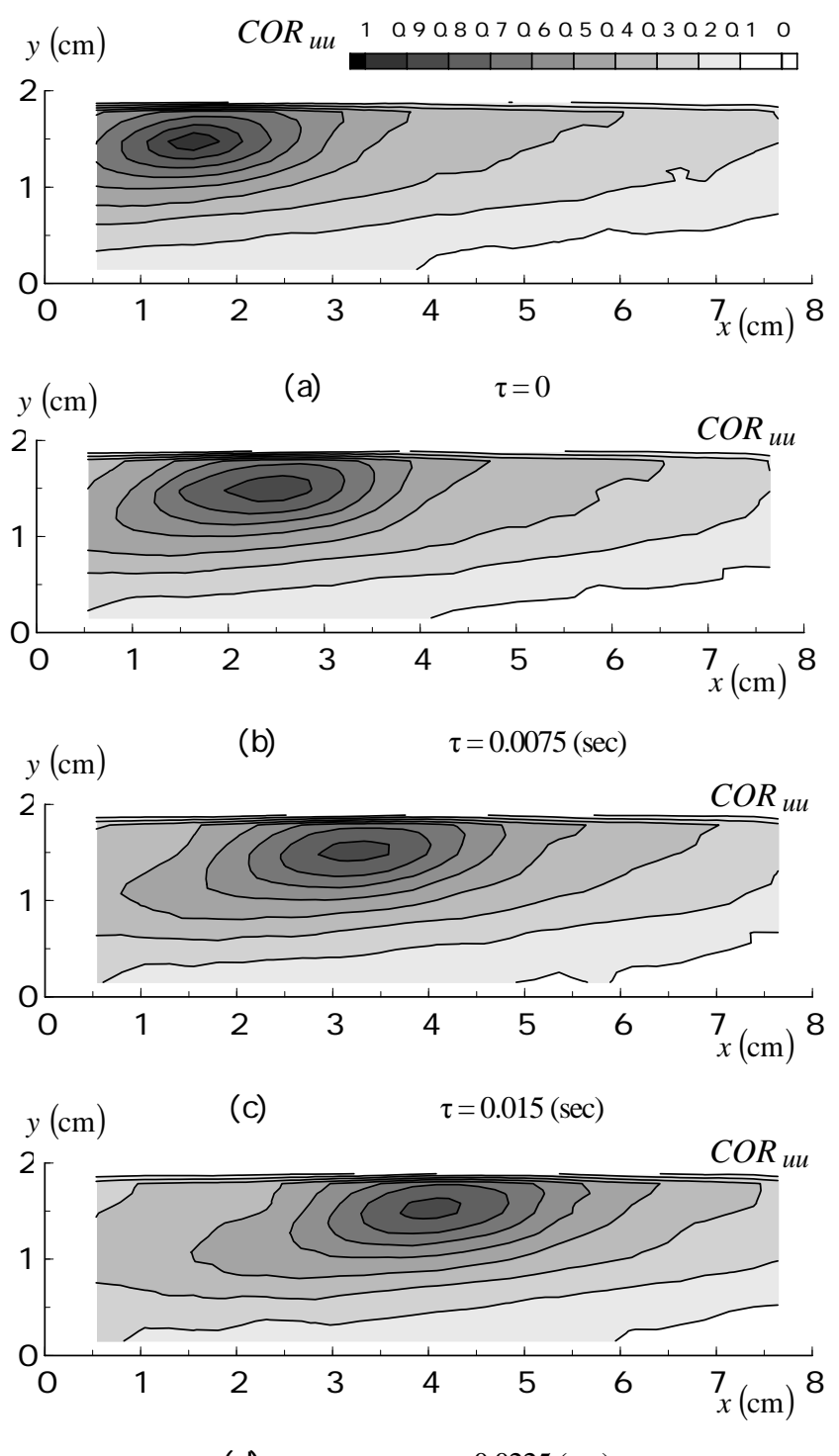

(d) ラグタイム $\tau=0.0225$ (sec)

図-7 $x$ 方向流速変動成分の時空間相関係数の空間分布 ( Case 1: $F r=2.33,\{x, y\}_{\mathrm{lef}}=\{1.56,1.47\}_{\mathrm{cm}}$ 参照位置 としている . )

成分 $h^{\prime}$ の自己時空間相関係数 $C O R_{h h}$ と同樣に, 図-7よ り，COR uはラグタイムT が大きくなるほど咸衰し，極 大值の現れる位置が流下方向に一定速度て移流していく 


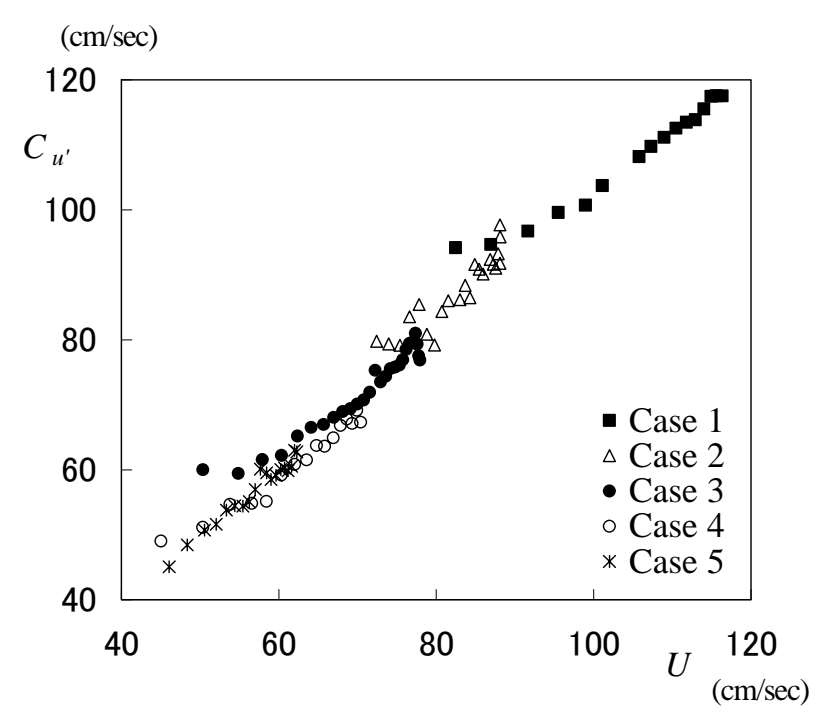

図-8 乱れの移流速度と時間平均流速の関係

ことがわかる.

図-6・7において示された, ラグタイムTに伴う自己 時空間相関係数の変化については, 実験の全Caseをとお して定性的に同じ傾向を示しており，各Caseにおいて極 大值の移動から移流速度力評価できることとなる．

\section{（5）水面変動·乱れの移流特性}

図-8は, 前述のようにして自己時空間相関係数 $C O R_{u u}$ の極大值から求め大流速変動成分 $u^{\prime}$ の移流速度 $C_{u^{\prime}}$ と , 時間平均流速 $U(y)$ との関係である . 図中の点は, $x_{\text {ref }}$ を一定にして $y_{\text {ref }}$ を水表面近傍から水路床近傍まて変化 させて算出したCOR uиを，光れ光れ対応する $U\left(y_{\text {ref }}\right)$ ごと にプロットしたものである . 図中での各シンボルのプ

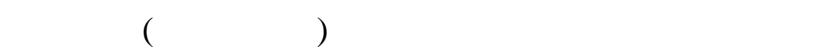
の值に, 左下のものか冰路床近傍での值に光れ光れ対応 する．これより，移流速度 $C_{u}$ ははほほ時間平均流速 $U(y)$ と 同じ值をとることがわかり，U(y)にのって乱れ $u^{\prime}$ か瀭送 されていること，すなわち，いわゆるTaylorの凍結乱流 の仮説10) が成り立っていることか確忍できる．

図-9は, 図-8と同樣にして求めた, 水面変動成分 $h^{\prime}$ の移流速度 $C_{h}$, と断面平均流速 $\bar{U}$ の関係である . 図中に おいて, シンボルロ・○は, 光れぞれ極大值の相関係数 が0.9・0.6以上のデータから求めた移流速度を表す. 従って, 後者○は前者口に比へてて長時間平均の移流速度 を算出したことに対応する．図より，すべてのCaseにお いて移流速度 $C_{h}$ （は断面平均流速 $\bar{U}$ より低い値をとって いることがかか. また , 水表面近傍での時間平均流速 $U(y)$ 力断面平均流速 $\bar{U}$ よりも大きい值をとることから， 水面変動成分 $h^{\prime}$ は, 关の位置 $y て ゙ の U(y) に$ に追随する内部 の流速変動成分とは異なり, 水表面近傍でのU(y)よりも かなり小さい值をとることがわかる．

次に, 水面変動成分 $h^{\prime}$ の移流速度 $C_{h^{\prime}}$ におけるフルー

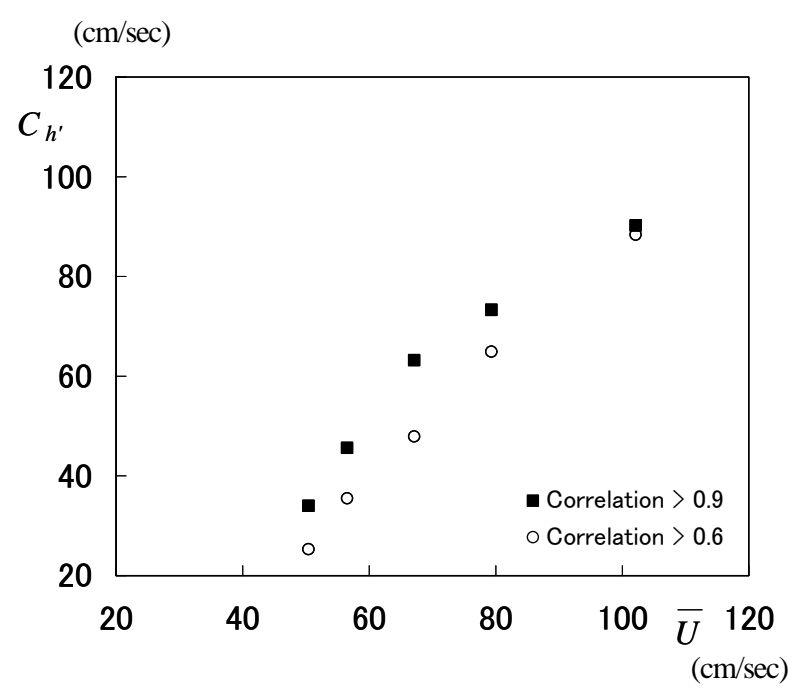

図-9 水面変動の移流速度と断面平均流速の関係

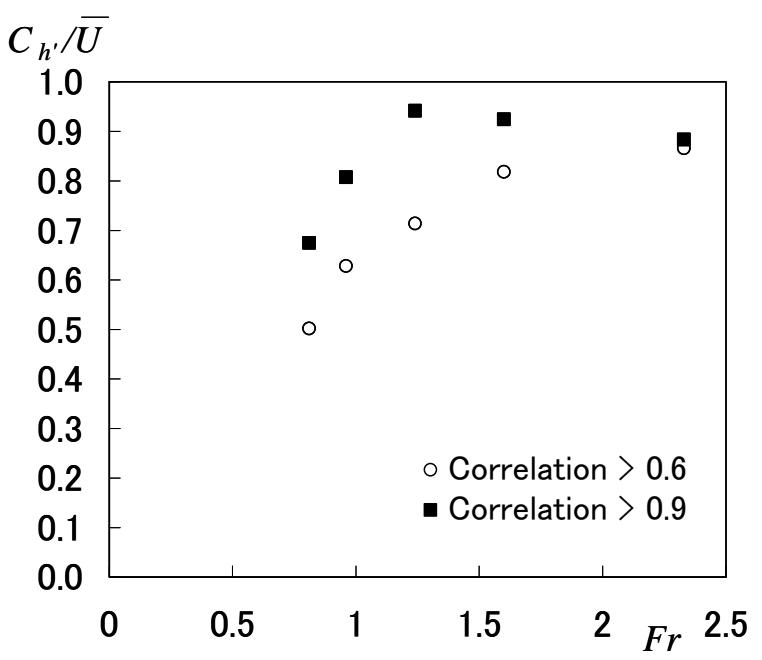

図-10 水面変動の無次元移流速度とフルード数の関係

ド数Frの依存性を検討する . 図-10は，断面平均流速 $\bar{U}$ て規準化した無次元移流速度 $C_{h}, \bar{U}$ とフルード数 $F r の$ 関 係である .これより，Fr数が小さなるにつれて $C_{h}, / \bar{U}$ が小さな值をとることがわかる.特に, フルード数が 1.0以下の常流条件においては, 水面変動成分 $h^{\prime}$ の移流 速度 $C_{h}$ は断面平均流速 $\bar{U}$ (もしくは, 水表面近傍での時 間平均流速 $U(y))$ に比べてかなり小さくなることがわかる .

以上の結果は室内水理実験により得られたものではあ るが , 実河川表面流の画像計測1),2)においても原理的に は同樣の相関解析を行っていることから, 水表面流速を 過小評価している可能性か沶唆される.ただし，これに 関しては, 本研究では計測值の相関解析を行って水面・ 流速変動間の関係を明らかにしている段階であり，今後， 計測されていない水路横断方向への水面変動伝播の影響 や実験水路スケールに起因する表面張力などの影響を考 慮に入れて解析を行い, 最終的な結論を導く必要がある. 
また，筆者らの前報における同時の空間相関解析 ${ }^{4}$ のから は, 同一空間スケールの水面変動と内部の流速変動には 有意な相関力確認されており，本研究で得られた結果と 合わせて , 今後 , 開水路流れにおける自由水表面の挙動 メカニズムも検討していく予定である .

\section{5. 結 論}

開水路乱流において, $R e=2.0 \times 10^{4}, F r=0.81 \sim 2.33 の$ 条件で室内水理実験を行い, 同時画像計測法により瞬時 の水面分布と流速ベクトルを測定した . 得られた計測値 に時空間相関解析を適用することにより，水面変動と内 部の乱れの移流特性を検討した . 得られた成果をまとめ ると，以下のようである .

（1）流速変動成分の移流速度は，光の位置での時間平均 流速とほぼ同じ值をとることがわかり，本実験の範囲に おいて，Taylorの凍結乱流の仮説が成り立っていること か確認された .

（2）一方，水面変動成分の移流速度は，時間平均流速に 追随する内部の流速変動成分とは異なり，断面平均流速 もしくは水表面近傍での時間平均流速よりも小さい值を とることがわかった .

（3）弚の水面変動の移流速度は, $F r$ 数か小さくなるにし たがって，断面平均流速に比べて，より小さな值をとる ようになる、特に , 本実験の範囲においては, 流れか常 流の条件となる場合に減少傾向か顕著である。

謝辞：本研究の実験を遂行するにあたり，当時神戶大学 学生であった下山顕治氏 , 稲岡克彦氏の協力を得た . 記 して謝意を表します。

\section{参考文献}

1) Fujita, I., Muste, M., and Kruger, A.: Large-scale particle image velocimetry for flow analysis in hydraulic applications, J. Hydr. Res., Vol.36, No.3, pp.397-414, 1998.

2) 藤田一郎, 河村三郎 : ビデオ画像解析による河川表面流計測 の試み, 水工学論文集, 第38巻, pp.733-738, 1994.

3) 宮本仁志, 神田 徹, 大江和正, 下山顕治 : 水面 ·流速の同 時画像計測法の開発と水面変動を伴う開水路凹部流れの解析， 土木学会論文集 , No.726/II-62, pp.41-53，2003.

4) 宮本仁志, 下山顕治 : 開水路流れにおける水面変動と乱れの 空間相関構造, 水工学論文集, 第47巻, pp.439-444, 2003.

5) Miyamoto, H. and Shimoyama, K.: Spatial correlation structures of water surface fluctuation with turbulence in open-channel shear flows, Journal of Hydroscience and Hydraulic Engineering, Vol. 22, No.1, pp.37-50, 2004.

6) Miyamoto, H. and Shimoyama, K.: Experimental study on influence range of water surface fluctuations in turbulent open-channel flows, The Sixth International Conference on Hydroscience and Engineering (ICHE-2004), Brisbane, Australia, Proc. CD-ROM, 2004.

7) 禰津家久, 中山忠暢 : 自由水面近傍の乱流構造と水面変動と の関連性に関する研究, 土木学会論文集, No.593/II-43, pp.69$78,1998$.

8) 禰津家久, 中山忠暢 : 自由水面近傍における組織渦の時空間 相関構造に関する研究, 土木学会論文集, No.586/II-42, pp.5160, 1998.

9) Nezu, I. and Nakagawa, H. : Turbulence in open-channel flows, pp. 53-62, IAHR-Monograph, A. A. Balkema, Rotterdam, 1993.

10) たとえば, Tennekes, H. and Lumley, J.L.: A first course in turbulence, pp.248-256, The MIT Press, 1972.

( 2005. 9. 30受付) 